Research article

\title{
SURVIVAL AND EVALUATION OF CLINICAL AND LABORATORY VARIABLES AS PROGNOSTIC INDICATORS IN HORSES HOSPITILIZED WITH ACUTE DIARRHEA: 342 CASES (1995-2015)
}

\author{
KOVAČ Milomir ${ }^{1 *}$, HUSKAMP Bernhard ${ }^{2}$, SCHEIDEMANN Wolfgang ${ }^{2}$, \\ TOTH Joseph ${ }^{2}$, TAMBUR Zoran ${ }^{3}$ \\ ${ }^{1}$ Veterinary Clinic - New Century, Skryabin Moscow State Veterinary Academy; Moskow, Krasnogorsky \\ district, Nikolo-Uryupino, 143421, Russia; ${ }^{2}$ Veterinary Clinic - Gescher-Hochmoor, Gescher, Germany; \\ ${ }^{3}$ Instittute of Hygiene, Military Medical Academy, Belgrade, Serbia and Faculty of Stomatology in \\ Pančevo, Pančevo, Serbia
}

(Received 04 May 2016, Accepted 13 Febrary 2017)

A retrospective study was performed on 342 horses with acute diarrhea (equine colitis). Clinical and laboratory data were obtained upon arrival at the equine hospital. The main focus of this study was to find the difference between the clinical and laboratory variables of surviving and deceased acute colitis horses before the beginning of medical treatment, with the aim to provide a better guideline for determining the prognosis of survival.

According to this retrospective study the lethality rate of acute equine colitis was 41.93 $\%$. The time interval from the onset of acute diarrhea to the horse being taken to the clinic was significantly longer in the case of horses which had not survived. The heart rate, hematocrit, blood $\mathrm{pH}$, blood hydrogen carbonate concentration, base excess and HCT/TPP ratio were shown to be significantly related to the survival of horses with colitis. Thus, the hematocrit, appeared to be the most relevant predictor of the outcome of acute equine colitis. Body temperature, respiration rate, total plasma protein and white blood cell count, did not show any prognostic significance.

Key words: horse, diarrhea, colitis, survival, prognosis

\section{INTRODUCTION}

A rapid onset form of acute diarrhea (equine colitis) occurs relatively frequently to horses all over the world. The etiology of equine colitis is clearly multifactorial. Even though many causes are known, colitis can be regarded as a syndrome that can be initiated by any infectious or noxious agent that can induce an inflammatory response in the caecum and colon [1]. The causes of equine colitis can be infectious (such as bacteria - Salmonella spp., Clostridium difficile, Clostridium perfringens) or non-infectious, *Corresponding author: e-mail: vet@newcentury.ru 
primarily as a result of antibiotic associated diarrhea and dietary imbalances, i.e. due to the eradication of normal gut flora [2-4]. Undiagnosed causes of peracute, often fatal colitis of horses is often referred to as Colitis X [5,6]. A causative organism for Colitis $\mathrm{X}$ has not been definitively identified, and, in fact, the etiology is likely multifactorial (associated with Clostridium spp. infection, stress and disruption of the intestinal microflora) [7,8]. Each etiology of acute equine colitis leads in a short time to massive fluid, electrolyte and protein loss, and because of this affected horses require intensive treatment against rapidly developing life-threatening endotoxic shock [9].

Horses with acute colitis on admittance to the equine hospital are frequently being at the terminal stage of the disease (endotoxic shock), so that successful therapy to such horses is made more difficult [10]. The substantial mortality rate and the expenses of treatment associated with colitis underscore the importance of identifying equine patients with a poor prognosis for survival. Making a correct survival prognosis for such horses is of great importance for the owner, for the animal and also for the equine clinic.

The purpose of the present study was to evaluate which clinical and laboratory variables and other factors obtained upon arrival at the equine clinic (i.e. before medical treatment) are of the best assistance for prognosis of the acute colitis horses.

\section{MATERIALS AND METHODS}

The present retrospective study included 342 horses with acute diarrhea referred to the Veterinary Clinic - Hochmoor (Germany) during the period from 1995 to 2005 (311 cases) and to the Veterinary Clinic - New Century (Moscow, Russia) during the period from 2006 to 2015 (31 cases). All horses were clinically (rectal temperature, heart and respiratory rate) and laboratory (hematocrit, total plasma protein, leucocytes count, blood $\mathrm{pH}$, base excess, bicarbonate concentration) examined immediately on arrival and the process was controlled during medical treatment at the equine clinic.

Hematocrit (HCT, packed cell volume) was analyzed by a capillary microcentrifuge using venous blood from the jugular vein. Total serum protein (TPP) was measured with a refractometer. Haematological variables were analyzed on Medicon CA620 (Medicon Pharmapark, Dublin, Irland). For blood gas analysis (pH blood, base excess, blood bicarbonate concentration) approximately $1 \mathrm{ml}$ of blood was collected from the transverse facial artery into a Pico 70 heparinized arterial blood sampler for immediate acid-base and blood gas evaluation on a Radiometer ABL 5 (Radiometer Medical A/S, Copenhagen, Denmark).

The hematocrit / total protein ratio was obtained from the following equation:

$$
\text { HCT } / \text { TPP ratio }=\frac{\text { Hematocrit } \mathrm{x} 100}{\text { Total protein }}
$$


The qualitative parameters (age, breed, gender) and medical records of horses with acute diarrhea were also reviewed to abstract information regarding the outcome and history, especially, how much time has passed between the onset of diarrhea symptoms and the beginning of medical treatment, as well as the date of clinicopathological and micrological testing performed and type of treatment carried out.

The study was performed over 2 periods of time and in two equine clinics. As the year of inclusion might have influenced the results, the same protocol for clinical and laboratory examination throughout the study was used to avoid such bias. Basic treatment in both equine clinics for all acute diarrhea horses was similar, including administration of large volumes of IV fluids, electrolyte replacement, correction of metabolic acidosis, restoring flora imbalance, as well as application of fluoroquinolone antibiotics such as enrofloxacin, NSAIDs such are flunixin meglumine, anticoagulants as heparin and prokinetic drugs like neostigmin [11]. If the acute diarrhea horse showed severe protein loss, plasma transfusions was performed.

The outcome for all analyses of acute diarrhea horses was did / did not survive. From a total of 342 horses with colitis, 199 survived and 143 did not survive. Exitus lethalis of acute diarrhea horses mostly occurred after several days of therapy regardless of intensive treatment. According to the hystopathological examination of the large bowel at post mortem, and examination and analysis of fecal microbial flora, in most of these acute diarrhea horses colitis could be determined due to Salmonellosis or Clostridium infection or/and Colitis $\mathrm{X}$, as well as equine colitis following antibiotic treatment. Sometimes, the use of strong antibiotics destroy the population of normal equine intestinal bacteria causing colitis as a result of irritation and inflammation of the colon mucosa. This results in a decrease of carbohydrate fermentation and fatty acid production, followed by reduced sodium and water absorption in the colon, increased secretion and altered motility. However, in many cases $(23 \%)$ of acute diarrhea no specific cause was found.

Chronic diarrhea caused by parasites and secondary diarrhea lasting 1-2 days caused by treatment with laxatives are excluded from this study. Due to the need to ensure that all horses were euthanized at the terminal stage of the disease, in this retrospective study were excluded all colitis cases that were euthanized for economical or other reasons.

Statistical analysis: The computer software "Statistics Analysis System - SAS" was used for the computation of statistical data. Initially, survivors and non-survivors acute diarrhea horses were compared with respect to the clinical and laboratory variables obtained before beginning the medical treatment. The computation of quantitative variables took place with the Student's t-test. Multivariable logistic regression was used to identify the influence of duration and other factors on survival. Qualitative variables were computed with the Chi-squared test. The research on statistical dependence between the clinical and laboratory parameters of surviving and deceased horses took place by means of a Pearson`s correlation tests. 


\section{RESULTS}

According to our observation, the great majority of horses that recover from acute colitis, typically show clinical improvement within 3-5 days after the treatment begins. Based on our study, 143 horses out of the 342 horses with acute diarrhea died or underwent euthanasia, thus the lethality rate was $41.82 \%$. Low survival rates of acute diarrhea were observed in horses with Clostridium infection or/and Colitis X, as well as colitis horses with a history of administration of strong antimicrobials. It is noticed that if horses with acute diarrhea show signs of colic, gastric reflux, watery-bloody consistency of diarrhea and complete loss of appetite they have a poor prognosis for clinical management and survival. The association between the year of inclusion and survival was not detected.

The time interval from the onset of acute diarrhea of the horse being taken for medical treatment in the equine clinic was significantly longer compared to deceased acute colitis horse (Table 1). Horses whose treatment began 24 hours after colitis symptoms have started had a low survival rate.

Table 1. Clinical and laboratory parameters in horses with acute diarrhoea

\begin{tabular}{|c|c|c|c|c|c|}
\hline Variables & $\mathbf{n}$ & $\begin{array}{c}\text { Survivors } \\
\text { Median }( \pm \text { SD) }\end{array}$ & $\mathbf{n}$ & $\begin{array}{l}\text { Non-survivors } \\
\text { Median ( } \pm \text { SD) }\end{array}$ & Significance \\
\hline Heart rate (bpm) & 199 & $63.19( \pm 20.35)$ & 143 & $80.43( \pm 22.41)$ & $\mathrm{p}<0.001$ \\
\hline Respiration rate (/min) & 91 & $23.71( \pm 12.88)$ & 60 & $26.31( \pm 12.24)$ & n.s. \\
\hline Temperature $\left(\mathrm{C}^{\circ}\right)$ & 152 & $38.04( \pm 0.66)$ & 102 & $38.27( \pm 1.88)$ & n.s. \\
\hline $\operatorname{HCT}(1 / 1)$ & 191 & $0.45 \quad( \pm 0.11)$ & 141 & $0.58 \quad( \pm 0.13)$ & $\mathrm{p}<0.001$ \\
\hline TPP (g/l) & 191 & $60.48( \pm 12.84)$ & 141 & $62.57 \quad( \pm 27.61)$ & n.s. \\
\hline $\mathrm{HCT} / \mathrm{TPP}$ ratio & 191 & $0.75 \quad( \pm 0.18)$ & 141 & $0.92 \quad( \pm 0.21)$ & $\mathrm{p}<0.001$ \\
\hline pH-Blood & 124 & $7.38 \quad( \pm 0.06)$ & 82 & $7.31 \quad( \pm 0.10)$ & $\mathrm{p}<0.001$ \\
\hline $\mathrm{HCO} 3-(\mathrm{mmol} / \mathrm{l})$ & 124 & $26.09( \pm 4.26)$ & 82 & $22.32( \pm 5.85)$ & $\mathrm{p}<0.001$ \\
\hline $\mathrm{BE}(\mathrm{mmol} / \mathrm{l})$ & 124 & $+1.04( \pm 4.12)$ & 82 & $-3.25( \pm 6.51)$ & $\mathrm{p}<0.001$ \\
\hline Leukocytes $\left(\mathrm{x} 10^{3} / \mu \mathrm{l}\right)$ & 75 & $7.12 \quad( \pm 4.05)$ & 53 & $5.16 \quad( \pm 4.44)$ & n.s. \\
\hline $\begin{array}{l}\text { Duration of acute colitis } \\
\text { before begin treatment (hours) }\end{array}$ & 101 & $8.23 \quad( \pm 7.32)$ & 68 & $18.02( \pm 11.56)$ & $\mathrm{p}<0.001$ \\
\hline
\end{tabular}

From the examination of clinical parameters obtained before treatment started highly significant differences $(p<0.001)$ between the surviving and deceased acute diarrhea horses was only in the case of heart rate (Table 1). The heart rate of 143 deceased diarrhea horses was on average 80.42 beats/min and of 199 survived patients 63.24 beats $/ \mathrm{min}$ (Table 1 ). A heart rate of under 60 beats / min was determined in 25 of 143 cases of death (17.49\%), while a pulse under 60 beats / min was found in 97 of 199 cases of surviving horses $(48.75 \%$ ). A heart rate of more than 100 beats / min before 
treatment was found in 32 cases of death (22.38\%), contrary to 14 surviving horses $(7.04 \%)$. No significant differences $(\mathrm{p}>0.05)$ in clinical variables of the respiration rate and body temperature between the surviving and deceased horses with acute colitis were found (Table 1).

Laboratory analysis obtained before the beginning of the treatment showed highly significant differences $(\mathrm{p}<0.001)$ between surviving and deceased horses including the following: hematocrit (HCT), base excess (BE), $\mathrm{pH}$ blood, hydrocarbonate concentration (HCO3-) and HCT/TPP ratio (Table 1). According to this study, of all examined clinical and laboratory variables hematocrit is the most valuable parameter regarding its prognostic value. The hematocrit value before the beginning of treatment of deceased acute colitis horses was on average $0.58 \mathrm{l} / \mathrm{l}$, and of surviving colitis horses $0.45 \mathrm{l} / \mathrm{l}$ (Table 1). A hematocrit value more than $0.65 \mathrm{l} / \mathrm{l}$ was found before the start of the treatment in 49 cases of deceased horses (34.26\%), in contrary to only 11 surviving horses $(5.52 \%)$. The hematocrit value less than $0.40 \mathrm{l} / \mathrm{l}$ before the beginning of the treatment, was found in only 15 cases of deceased horses $(10.49 \%)$, compared with 78 surviving horses $(39.19 \%)$.

Blood $\mathrm{pH}$ under 7.30 was found in 54 cases of deceased colitis horses $(37.76 \%)$ and only in 17 surviving cases $(8.54 \%)$. According to our retrospective study the white blood cell count obtained before the beginning of the treatment showed a very broad standard deviation in deceased acute colitis horses, i.e either leukopenia $(<5000 / \mu \mathrm{l})$ or leukocytosis $(>10000 / \mu \mathrm{l})$ were often found in these colitis patients.

Before the beginning of treatment, no significant differences ( $p>0.05)$ were determined between the surviving and deceased horses in total protein content in the blood, but not surviving acute colitis horses showed a very broad standard deviation, i.e either a total protein content more than $70 \mathrm{~g} / \mathrm{l}$, or hypoproteinemia $(>50 \mathrm{~g} / \mathrm{l})$ was often determined in this group of animals (Table 1). Based on our observation, if the plasma total protein values drop continuously in horses with acute colitis despite intensive therapy, and the hematocrit value maintains at a high level, it surely presents a very unfavorable prognostic sign. During a favorable process the protein loss adheres within limits and the hematocrit value already stabilizes until the end of the second day of acute colitis. If a horse does not improve over the first two or three days then the prognosis is poor.

\section{DISCUSSION}

Acute diarrhea as a consequence dysbiosis and inflammation of the large bowel caecum and colon of a horse (equine colitis) is one of the life-threatening conditions that require intensive and expensive treatment. According to our retrospective study the lethality rate of acute equine colitis was $41.93 \%$. The factors leading to the deadly outcome of horses with acute diarrhea are various, but the principal reason for a fatal outcome is a systemic endotoxic shock following intensive liquid and electrolyte loss, 
acidosis, disseminated intravascular coagulation and kidney insufficiency [9,12]. The survival percentage in the present study is at a similar level as reported from other studies on hospitalized equine colitis cases, and ranges from 20 to $88 \%$, depending on the virulence of the pathogen, the susceptibility of the host, and the aggressiveness of the therapy [13-15]. Positive blood cultures (bacteriemia) occur more frequently and may have a negative impact on the survival of horses with acute diarrhea [16].

The time interval from the first symptom of acute diarrhea to the beginning of intensive therapy plays a crucial role in the survival of equine acute colitis, since significantly contributes to the development of irreversible endotoxic shock. For this reason, in our opinion the most important factor in survival of acute colitis horses is to minimize the time interval from the onset of acute diarrhea to the horse being taken to medical treatment, because a delay of few hours significantly reduces the percentage of survival. In the best scenario it should begin with the treatment of acute diarrhea horses in the prodrome stadium of disease. An early recognition in connection with an aggressive correction of the dehydratation and the acid base status are crucial for a successful treatment. It is a common view that despite intensive therapy lethality is very high in horses with acute colitis, so further intensive research in the range of an early diagnosis and a therapy of such illnesses is necessary [17].

It is also very important to establish the exact cause of the equine colitis, because initial prognosis depends primarily upon whether a specific etiology and/or disease process can be determined or not [6]. It is known that diarrhea caused by Salmonella has a lower mortality than acute diarrhea in horses caused by Colitis X [15]. As it is mentioned in the literature the development of equine colitis and the probability of a lethal outcome is substantially higher in surgically treated patients, as well as in the case of pretreatment with potent antibiotics (e.g. lincomycin) [18,19]. A weak immune response due to a strong stress syndrome increases substantially the lethality rate [9]. Complications of equine acute colitis such as the laminitis or thrombophlebitis also worsen the prognosis [20,21].

There are few retrospective statistical investigations of survival and prognosis of equine acute colitis $[10,13,14,16,22]$. In these studies it is common that the prognosis is derived from one "relatively" low number of acute colitis cases. To achieve these goals, we consider that only a high number of acute equine colitis cases can create a solid prognostic model that accurately reflects the patterns existing in the underlying data. According to our study, assessment of the cardiovascular function was a good prognostic guide. There are highly significant differences between the surviving and deceased horses before the beginning of treatment, only in the heart rate, but not in body temperature and respiration rate. Kemper [5] and Cohen and Woods [10] found that acute diarrhea horses with a heart rate of more than 60 beats/min have a significantly increased lethality rate.

According to this study, laboratory variables such as hematocrit, acid - base variables (base excess, hydrogen carbonate, $\mathrm{pH}$ - blood) and HCT/TPP ratio are also very 
valuable prognostic predictors. The hematocrit value shows the most significant difference between the surviving and deceased horses, i.e. the hematocrit value is proven to be the most valuable prognostic value from all examined clinical and laboratory parameters. It has long been known, that serious dehydration as the main symptom of endotoxic shock is the most common cause of a high hematocrit. This was confirmed by other investigations $[10,13]$.

Based on our research there is a direct correlation between the degree of acidosis in the blood and survival of the acute colitis horse. As it is known, metabolic acidosis is the best indicator in early endotoxic shock of ongoing oxygen imbalance at the tissue level. According to the results of a multivariate variable analysis [14], among the variables tested in the cases of acute equine enterocolitis, the decreased blood $\mathrm{pH}$ and increasingly negative base excess were the best predictors of death or survival. This is the reason, why upon arrival at the equine hospital immediate determination of the hematocrit and arterial blood measures of metabolic acidosis are very important in the clinical management and survival of acute diarrhea horses [23].

We found no significant differences between surviving and deceased horses with acute diarrhea concerning the total protein content in the blood. However, either hypoproteinemia or hyperproteinemia was frequently found in deceased horses (strong deviations from the normal values). According to Coohen and Woods [10] and Dollente et al. [12] the plasma protein content deviating from the standard value (hypoproteinemia) is a bad prognostic indicator in horses with acute diarrhea. Kamper [5] found that a hyperproteinemia can exist in the early stage of Colitis X, but after several hours the plasma protein content decreases continuously due to intramural exudation and losses through the inflamed intestinal wall (protein losing enteropathy). Based on our results, despite the insignificant changes of the total protein content, but because of the very high hematocrit value, a significant increase of the hematocrit / TPP ratio was determined in not surviving horses with acute diarrhea.

According to our earlier investigation [23] on statistical correlations between the examined clinical and laboratory parameters before the beginning of the treatment, there is a generally higher correlation in horses with fatal colitis than in surviving patients, i.e. in deceased horses 4-5 of the examined parameters showed very often "maximum abnormal values" simultaneously. In other words, in not surviving horses with acute colitis, a decompensated endotoxin shock was already noticed on admission of horses to the equine clinic.

Based on our earlier studies no significant differences in survival of horses with acute colitis in age, breed, gender and year of inclusion were recorded [23]. There are several investigations handling this problem and confirming this result $[17,18]$, but some studies have reported that older horses have a higher risk of dying from acute colitis [5].

Finally, one must point out that each horse with acute diarrhea shows a broad spectrum of different pathological signs, so an exact prognosis is difficult. Apart 
from the examined variables in our study, other different factors can be important for the prognosis in horses with acute diarrhea, such as: serum electrolyte and lactate concentrations, azotemia, hypoalbuminemia, alkaline phosphatase, serum creatinin and urea concentration, increased concentrations of free hemoglobin and tumor necrosis factor-alpha in the blood [10,13,14,24-26].

In conclusion, the prognosis of acute equine colitis depends on the severity and degree of endotoxic shock and response to therapy within the first two or three days, i.e prognosis should not be limited only to the first examination, but should be continued in the form of a process and depends upon the disease development and if necessary must be corrected. If the horse improves within one or two days, the prognosis is usually good, because, according to our observation exitus lethalis of equine acute colitis occurs mostly after several days of therapy. If a colitis horse does not improve over the first two to three days or symptoms worsen then the prognosis is poor.

\section{Authors' contributions}

KM have made substantial contributions to conception and design, or acquisition and anlysis of data, and inerpretation of data; have been involved in drafting the manuscript or revising it critically for important intellectual content; participated in the laboratory analysis. HB have made to substantial contributions to idea to investigation and contributions to conception. SW and TJ conceived to the study, participated in the laboratory analysis and interpretation of data. $\mathrm{TZ}$ participated in the statistical analysis and been involved in drafting the manuscript or revising it critically for important intellectual content.

\section{Declaration of conflicting interests}

The author(s) declared no potential conflicts of interest with respect to the research, authorship, and/or publication of this article.

\section{REFERENCES}

1. Larsen J: Acute colitis in adult horses. A review with emphasis on aetiology and pathogenesis. The Veterinary Quarterly 1997, 19(2): 72-80.

2. Oliver OE, Stampfli H: Acute diarrhea in the adult horse: case example and review. Vet Clin North Am Equine Pract 2006, 22(1): 73-84.

3. Baverud V: Clostridium difficile diarrhea: infection control in horses. Vet Clin North Am Equine Pract 2004, 20(3) 615-630.

4. Gohary IM, Arroyo L, Macinnes J, Timoney JF, Parreira VR: Characterization of Clostridium perfringens in the feces of adult horses and foals with acute enterocolitis. Can J Vet Res 2014, 78(1) 1-7.

5. Kemper P: Klinisch-pathologische und histologische Untersuchungen zur Pathologie und Pathogenese der Typhlocolitis beim Pferd. Inaugural Doktor Dissertation, Hannover, 1995. 
6. Merritt AM: Adult Equine Diarrhea Workup. Proceedings of the Annual Convention of the AAEP. 1999, 45: 276-281.

7. Bartmann CP, Verspohl J, Amstberg G, Deegen W: Clinical and Bacteriological Investigations About the Aetiology of Colitis $\mathrm{X}$ in the Equine. in 6th Colic Research Symposium, Georgia, 1998, 10.

8. Glenn Songer, J, Trinh HT, Sharon M, Brazier JS, Glock RD: Equine Colitis X Associated with Infection by Clostridium difficile NAP1/027. J Vet Diagn Invest 2009, 21(3): 377-380.

9. Kovac M: Acute colitis. In - Колики мошади - Причина. Аиагноз. Аечение. Publ. -Королевский издательский дом, Moskva, 2010, 138-146.

10. Cohen NC, Woods A: Factors associated with survival among horses with acute diarrhoea. in 6th Colic Research Symposium, Georgia, 1998, 12.

11. Kovač M: Akutna upala sluznice velikog kolona. In. Količna oboljenja konja - Veterinarska Komora Srbije, Beograd, 2002, 73-76.

12. Dolente BA, Wilkins PA, Boston RC: Clinicopathologic evidence of disseminated intravascular coagulation in horses with acute colitis. J Am Vet Med Assoc 2002, 220(7) 1034-1038.

13. Mair TS, Weserlaken LV, Cripp PJ: Diarrhoea in adult horses: A survey of clinical cases and an assessment of some prognostic indices. Vet Rec 1990, 126: 479-481.

14. Staempfli HR, Townsend H, Prescott J: Prognostic features and clinical presentation of acute idiopathic enterocolitis in horses. Can Vet J 1991, 32: 232-237.

15. Odenkirchen S, Huskamp B: Akute Durchfallerkrankungen bei Pferden unter besonderer Berücksichtigung der Salmonellose und Typhlokolitis. Dtsch Tierärztl Wschr 1995, 102(5): 235-241.

16. Johns I, Tennent-Brown B, Schaer BD, Southwood L, Boston R: Blood culture status in mature horses with diarrhoea: a possible association with survival. Equine Vet J 2009, 41(2): 160-164.

17. Feary DJ, Hassel DM: Enteritis and colitis in horses. Vet Clin North Am Equine Pract 2006, 22(2): 437-479.

18. Cohen NC, Honnas CM: Risk factors associated with development of diarrhoea in horses after celiotomy for colic: 190 cases. J Am Vet Med Assoc 1996, 209(4): 810-813.

19. Champen AM: Acute diarrhea in hospitalized horses. Vet Clin North Am Equine Pract 2009, 25(2): 363-380.

20. Scheidemann W, Kovac M: Laminitis as a complication of gastrointestinal disease Early diagnosis and therapy. Proceedings of XII Congress of Equine Medicine - Essen, Germany, 1999, 33-34.

21. Parsons CS, Orsini JA, Krafty R, Boston R: Risk factors for development of acute laminitis in horses during hospitalization: 73 cases (1997-2004). J Am Vet Med Assoc 2007, 230(6): 885-889.

22. Van Duijkeren E, Sloat van Oldruitenborgh-Oosterbaan M, Breukink HJ, Vulto AG: A survey of horses with acute diarrhoea: Diagnosis, assessment of the prognosis, and comparison of two antibiotic therapies. The Veterinary Quarterly 1996, 18(4): 153-156.

23. Kovac M, Scheidemann W, Toth J, Huskamp B, Trailovic D: Study of variables commonly used in examination of equine acute colitis cases to assess prognostic value. In: Proceedings of 10th Congress of the World Equine Veterinary Association, Moskow, 2008, 57. 
24. Kyaw WO, Uhlig A, G.Koller G, Sack U, Schusser GF: Free hemoglobin and tumor necrosis factor-alpha in the blood of horses with colic or acute colitis. Berl Munch Tierarztl Wochenschr 2008, 121(11-12): 440-445.

25. Tennent-Brown BS, Wilkins PA, Lindborg S, Russell G, Boston RC: Sequential plasma lactate concentrations as prognostic indicators in adult equine emergencies. J Vet Intern Med 2010, 24(1):198-205.

26. Hashimoto-Hills S, Magdesian KG, Kass PH: Serial measurement of lactate concentration in horses with acute colitis. J Vet Intern Med 2011, 25(6): 1414-1419.

\title{
PREŽIVLJAVANjE I PROGNOSTIČKA OCENA KLINIČKIH I LABORATORIJSKIH PARAMETARA KOD KONJA SA AKUTNOM DIJAREJOM: 342 SLUČAJA (1995-2015)
}

\author{
KOVAČ Milomir, HUSKAMP Bernhard, SCHEIDEMANN Wolfgang, \\ TOTH Joseph, TAMBUR Zoran
}

Retrospektivna studija izvedena je na 342 konja sa akutnom dijarejom (akutni kolitis konja). Klinički i laboratorijski podaci dobijeni su po dolasku u veterinarsku kliniku. Glavni cilj ove studije je bio da se pronađu razlike između kliničkih i laboratorijskih parametara pre početka lečenja i na kraju lečenja među preživelim i uginulim konjima od akutnog kolitisa, sa ciljem da se obezbede bolje smernice za određivanje prognoze preživljavanja kod ove bolesti.

Prema urađenoj retrospektivnoj studiji procenat smrtnosti kod akutnog kolitisa konja je 41,93\%. Vremenski interval od početka simptoma akutne dijareje do početka lečenja konja bio je znatno duži u slučaju uginulih konja. Srčana frekvencija, hematokrit, pH krvi, koncentracija hidrogen karbonata, bazni višak krvi i odnos hematokrita/koncentracije proteina u plazmi pokazuju da imaju signifikantni prognostički značaj pri akutnom kolitisu konja. Od svih ispitivanih parametara, vrednost hematokrita, pokazuje najvažni prognostički značaj za ocenu ishoda lečenja u životinja sa akutnim kolitisom. Na osnovu izvedenih ispitivanja, temperatura, frekvencija disanja, koncentracija ukupnih proteina plazme i koncentracija leukocita nije pokazivala signifikantan prognostični značaj. 